\title{
Measurement Dimensions for Arabic Language Teachers in Malaysia
}

\author{
M. al-Muslim ${ }^{1} \&$ Zamri Arifin ${ }^{1}$ \\ ${ }^{1}$ Department of Arabic Studies and Islamic Civilization, Faculty of Islamic Studies, Universiti Kebangsaan \\ Malaysia, Malaysia \\ Correspondence: M. al-Muslim, Department of Arabic Studies and Islamic Civilization, Faculty of Islamic \\ Studies, Universiti Kebangsaan Malaysia, Malaysia. Tel: 60-13-935-8650. E-mail: almuslim@ukm.edu.my
}

\author{
Received: June 16, 2014 Accepted: September 19, 2014 Online Published: October 30, 2014 \\ doi:10.5539/ass.v10n22p48 URL: http://dx.doi.org/10.5539/ass.v10n22p48
}

\begin{abstract}
Arabic language education in Malaysia has been considered unsuccessful. Therefore, Arabic language teachers as the main factor behind the success of school education system need to be transformed via a preparation, construction and evaluation of teacher quality. Hanna and Gimbert (2011) proposed three major initiatives in teacher quality evaluation beginning with identifying the dimensions in teacher quality. Subsequently, this paper has set upon two objectives, namely (a) to study the dimensions of teacher quality among the scholars, and (b) to identify the best dimensions for quality measurement of Arabic language teachers. The two objectives were achieved through a descriptive qualitative research via literature review of the views and works of previous scholars. A thematic approach was employed in the filtering process and data analysis with the help of Altas.ti version 7.1 software. Results of the study found that a diversity of teacher quality dimensions had been used in most of previous researches namely, teacher qualification, teacher characteristics, and in-class practice teaching effectiveness. This study has also identified a framework proposal for quality measurement dimensions for Arabic language teachers. In addition, this working paper also suggests a further study to complete the dimension framework proposal together with several aspects which need to be emphasized.
\end{abstract}

Keywords: teacher certification, teacher characteristics, teacher practices, teacher quality, teaching effectiveness

\section{Introduction}

Teaching is a noble profession. For Muslims, this profession is a continuation of the duty of the Prophets. Therefore, teacher has a special position in the society's view. Today, the change of time brings teaching profession to a more challenging level. In line with the progress and current needs, teachers face various demands. Not only are they responsible for the students but also they are to play a dominant role in realizing the inspirations of the religion, nation and the state as listed in the national education philosophy. The whole nation depends upon the effectiveness and efficiency of each teacher executing their duties. Teachers who teach the Arabic language to the sons and daughters of the Malaysian nation are of no exception. They carry a huge responsibility in their own field in line with the current challenges of Arabic language education (Yaakub, 2007). Their biggest challenge is to return Arabic language education to a position at par with its special position in the nation's education system and in the culture of the Malaysian majority community. This is due to that Arabic language education has so far been concluded as unsuccessful (Rejab, 1992). The special position of the Arabic language in the national education and the current situation of the Arabic language education add more burdens of responsibility which must be discharged by all Arabic language teachers. The success in overcoming these challenges and carrying the weight of the nation's trust lies in the competency and quality of the existing Arabic language teachers. Behind these challenges, a pertinent and urging question remains; does the prepared Arabic language teaching force fulfill the criteria of a true language teacher? (Mat \& Soon, 2010)

In the context of student learning, quality teacher is a factor which plays an important role. Even though there are other factors which can influence student performance such as student demography and educational background and economic and social status, teacher quality is more dominant and significant. In fact, teacher quality is more of value to the student performance than other investments in the improvement of the education system such as reduction of number of students per class by adding new classes, salary increment for teachers and all expenses related to education (Andrews, 2012; Croninger, Rice, Rathbun, \& Nishio, 2007; Goe, 2007; Lovat \& Toomey, 2009). Therefore, should a transformation in the Arabic language education be initiated in Malaysia, the main focus would be to develop and prepare quality teachers capable of confronting the current education challenges. 
Priority in the transformation policy must be set based upon a general consensus among scholars which states that teacher quality is the most influential factor in student achievement (Anonymous, 2010).

There would be no good education without good teacher quality (Lin, Xie, Jeng, \& Huang, 2010)

To realize the focus of developing and preparing quality teachers, Hanna \& Gimbert (2011) proposed three main steps in stages;

1) Identifying and defining dimensions of teacher quality;

2) Developing instruments capable of measuring the dimensions;

3) Developing and testing models of teacher quality that account for the multi-dimensional nature teaching and learning.

In line with the proposal by Hanna and Gimbert (2011) and as a commencement of Arabic language education transformation in Malaysia, this paper set its main objective as to identify dimensions in the measurement of Arabic language teacher quality. The objective of this study is achieved through a literature review of scholars' views and researches which later is synthesized into general dimensions of Arabic language teacher quality. The outcome is an initial framework proposal for the measurement of Arabic language teacher quality as presented towards the end of this article.

\section{Method}

This study is a descriptive form of qualitative research. The main source of study was previous studies. Data were extracted and analyzed from sources via a thematic approach. The extraction process was carried out with the assistance of Atlas.ti version 7.1 software. This process was completed with an auto-coding function in the software using a teacher quality theme as search keyword. As a result, there were 150 excerpts obtained within the theme of teacher quality. After that, data filtering and analysis were manually done by considering the approach and dimensions used in understanding teacher quality concept as well as suggestions and criticisms among the scholars. Results of the analysis were later organized based on the need of the pre-determined research objectives.

\section{Results}

\subsection{Concepts of Teacher Quality}

Teacher's role in the success of education has long been agreed upon. The factor of quality teachers is by far ahead of other factors especially in the context of learning at schools (School-Based Factor). Therefore, the concepts of teacher quality and their understanding have been deliberated since the 1970's and are still being talked about until today (Blanton, Sindelar, \& Correa, 2006). However, the definition and measurement of teacher quality are still vague and hotly debated.

Ambiguity in the definition of teacher quality does not mean that there is no indicator used as a proxy for quality teachers. In fact, numerous researches on quality measurement have been carried out based on specific criteria (Goe \& Stickler, 2008). Nevertheless, teacher quality is still considered unclear due to an absence of consensus among scholars in the meaning and dimensions which represent teacher quality concepts (Blanton et al., 2006; Burnett \& Meacham, 2002; Fuller, Young, \& Baker, 2010; Goe, 2007). Also, according to Cavalluzzo (2004) there is no consensus on the behaviors which contribute to quality teaching.

According to Goe (2007), in conclusion there are 4 fundamentals debated as dimensions to understand and subsequently measure teacher quality: (1) qualification, (2) characteristics, (3) in-class practices, and (4) effectiveness. These fundamentals individually have their own merits and weaknesses.

\subsubsection{Teacher Qualification}

Teacher qualification covers indicators and variables such as education level, certificates, teaching experience, teaching qualifying test and credentials. Traditionally, these indicators have long been used and considered as symbols for quality teacher even without being linked to student performance (Fuller et al., 2010). Different from process-product models, teacher qualification is often viewed as part of the input. Among policy makers, the definition of quality teacher which carries the meaning of 'fully qualified' is easier to accept than definitions by researchers in the teaching field. The acceptance is due to the fact that policy makers need information and fast and accurate measurement to facilitate their communication with the public (Blanton et al., 2006). Hence, the authority is seen to be putting efforts to prepare highly qualified teachers for placement in schools by creating special education system for teachers, listing educational certification and lately enactment of teacher act and standard such as the Standard Guru Malaysia (Malaysian Teacher Standard) 2011. 
Around the same time, Andrews (2012) questioned whether qualification as set by the No Child Left behind Act (NCLB)-for example-can bring about student progress especially when it involves new teachers. Is the teacher considered highly qualified without looking at student performance at the end of the year? To Andrews, fulfilling the standard and passing qualifying tests do not guarantee teacher quality. From that angle, Goe (2007) stated that the biggest deficiency in such definition is the probability of highly qualified teachers performing badly in real class situation. Moreover, these indicators are too general and there is no way of determining which characteristics, items or processes contribute and directly influence good teaching or student achievement (Croninger et al., 2007). Overall, these traditional parameters do not significantly represent changes in student progress compared to other parameters (Buddin \& Zamarro, 2009; Gallagher, 2004; Isaacs et al., 2012).

Nevertheless, there are researches which have shown a close link and consistency between certain qualification and student progress. For example, research into mathematics students found that a degree qualification in mathematics and related certificate had consistent relation with student achievement in mathematical subjects (Goe, 2007). Andrews (2012) also affirmed that latest research proved that the level of teacher expertise significantly influences student progress.

Taking conflicting research into consideration, most probably certain qualifications are effective in certain subjects as opposed to other subjects or for a specific period. For example, experience is important for the first few years only (Goe, 2007). This scenario calls for more related research at a larger scale.

\subsubsection{Teacher Characteristics}

According to Goe \& Stickler (2008), teacher quality is often singularly understood as teacher characteristics. Therefore, characteristics are rarely measured with student achievement. The terminology of 'characteristics' in general encompasses behaviors, attitudes, styles, beliefs, immutable characteristics such as gender, ethnicity and race as well as certain abilities like the ability to speak in the target language. In short, characteristics are what a teacher carries in himself into the class. A drawback in defining teacher quality using characteristics is that some characteristics are difficult to change and some are immutable (like natural characteristics of race and gender) while many are almost impossible to synchronize with the research output. In some circumstances, teacher characteristics is also difficult to measure (Lavy, 2011).

Empirical evidence has so far failed to specifically identify which teacher characteristics can be linked to high achievement (Buddin \& Zamarro, 2009; Smith \& Gorard, 2007). On another viewpoint, researchers such as Croninger et al., (2007) stated that there is proof that teacher characteristics reflect student achievement in reading skill. This was supported by a study by Ehrenberg, Goldhaber \& Brewer (1995) which found that teachers might appraise differently based on gender. The same study however showed that teacher characteristics such as gender, race and ethnicity did not affect student achievement.

All the while various studies have been carried out. However, no explicit conclusion can be made as to which teacher characteristics have an impact on student achievement. While some researchers found significant link for some variables, others found otherwise. According to Lee (2010), there was agreement on some general teacher characteristics suitable for various subjects. Nevertheless, there was no consensus on specific teacher characteristics for certain disciplines. Because of that, Goe (2007) opined that more studies in this scope are necessary to determine more holistic evidence.

\subsubsection{In-class Practices}

One of the many teacher quality definitions presented in studies concerns practices in the classroom. In-class practices refer to behaviors and attitudes of teaching. Normally, such studies used observations or self-assessment reports as research instruments. Teacher standard is a quality measurement often considered in determining teacher practices. This is based on the objectives of standards development itself which are to observe practices, knowledge and teacher ability to prepare quality learning opportunities. The United States in particular has introduced its own standard to prepare highly capable teachers. The National Board For Professional Teaching Standards (NBPTS) formed in 1987 is the only teacher quality measurement system which finds its place in numerous studies on content reliability (Ingvarson \& Rowe, 2007). Malaysia too introduced its own Standard Guru Malaysia (The Malaysian Teacher Standard) and is extensively used in self-assessment exercises.

According to Darling-Hammond (2009), the problem with the current teacher quality measurement is that measurement is often not correlated with teaching ability. The authority in particular much depends on principal's reports, records of attended courses or results of tests on skills and general knowledge of the subject. All these indicators are too weak to describe classroom effectiveness performance. To him, underlying the 
importance of teacher's knowledge, skills and others, it all depends on the way teacher handles the class (Darling-Hammond, 2012).

Nevertheless, the effectiveness of teacher practices on student achievement is often disputed. Even though most studies in this scope showed positive links between classroom teacher practices and student achievement, the findings in general were statistically and practically insignificant. In fact, some studies can be questioned as to their research design, research data or instruments which were possibly inconsistent with research objectives. To summarize, there is a deficiency in terms of result validity and reliability (Goe, 2007).

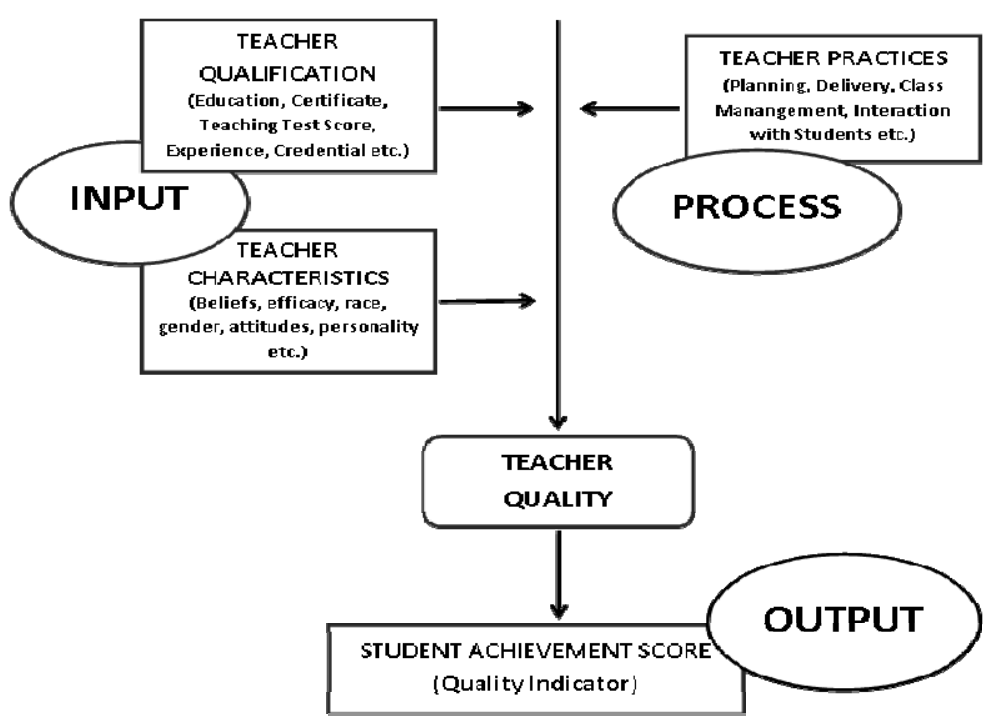

Figure 1. Differences of four fundamentals in the definition of teacher quality (Adapted from Goe (2007))

\subsubsection{Teaching Effectiveness}

Effectiveness is considered as a component or product of work of quality teacher. Quality teacher is one who has a positive impact on student achievement. Nowadays, examination results are often used as indicators of teacher quality. In addition, the use of student output, in particular their performance in examination as measurement of teacher quality, receives strong support and credibility from education professionals and the authority themselves. This is a result of extensive implementation of standardized tests in schools. Student achievement scores in such tests which are readily available became the attracting factor to use them in research on teacher quality (Blanton et al., 2006).

Value-added models are among the well-known measurement models among researchers and often employed for appraising, selecting and determining quality teacher. This model is specifically designed to pin-point contribution or effect of teacher on student achievement scores for a specific duration. Based on that objective, it has been used in studies of teacher quality to identify teacher effectiveness onto student achievement. However, the issue of lack of parametric approach and uncertainty in teacher specific characteristics which affect student scores in this added value model triggered many questions on, in particular, aspects of assessment and government policies (Hanushek \& Rivkin, 2010)

According to Goe (2007) there are three issues which impair the definition of teacher quality using student achievement test scores only.

1) Standardized achievement test were purposely designed to measure student achievement. They were not intended to assess teacher quality.

2) It is difficult to determine which and to what extent the product is resultant from the effect of the teacher factor or the class factor.

3) It is also difficult to obtain data which link specific student score with specific teacher.

She also questioned the practicality of teacher quality definition which is only determined by effectiveness. How do the responsible parties determine who is qualified to teach for the first time, while his students have not been assessed. 


\section{Discussion}

\subsection{Diversity of Measurement}

Much has been done in research on teacher quality. Since there is no consensus among the researchers on the definition of teacher quality, studies on teacher quality have been conducted with various objectives, research designs and measurements. All parties be they politicians, philosophers, government authorities, school administrators, students, researchers and even teachers themselves hold their own view on the concepts of teacher quality (Burnett \& Meacham, 2002). This difference in views occurs due to some reasons. One of them is the understanding of the teacher quality concepts of either a good teacher or an effective teacher. Fenstermacher \& Richardson (2005) were the first to reevaluate the meaning behind the term "teacher quality" which differentiates between good teaching and effective teaching. Teacher quality which carries the meaning of good teaching only concentrates on process and input whereas successful teaching takes into account changes in the target group particularly students. At around the same time, another group of researchers defined teacher quality as having both meanings (Blanton et al., 2006).

Mixed and uneven measurement also occurs due to the factor of different objectives. Policy makers usually desire fast and accurate data to ease communication of their policies with the public. They therefore tend to opt for aspects of qualification and test results which can easily be measured and meet their requirement. In fact, there are studies which tend to have the same line of thinking so their findings are more consistent and 'straight to the point'. This can be seen through the extensive use of value-added models for ascertaining the level of teacher quality. Their objective may be different from that of other researchers. They are more interested in deep understanding of teacher quality concepts via dimensions which are seen related.

According to Burnett \& Meacham (2002), a diversity in the definition and measurement of teacher quality, apart from the research objective factor, is affected by the difference in source of data, multitude of data interpretation and the choice of sample. At the same time, areas in teaching profession are diverse and varied especially in terms of their objectives and teaching and learning approach (Jasmi, 2010). Areas which nurture skills such as the Arabic language surely need teachers with specific approach and technique, apart from having language skills. The scenario is different for subjects who stress on facts such as history and economy.

Therefore, a conclusion can be made that disagreement and ambiguity in defining teacher quality are neither due to studies on teacher quality being weak nor their attainment being not at par with research in other areas. They are due to the natural vastness of the teacher quality term to the extent that it can be interpreted with various understanding which in turn brings forth different dimension measurement. This statement is important for it will determine how or through what quality Arabic language teachers will be identified.

\subsection{Measurement Dimensions}

What happens in the current world of teacher measurement embarked upon the criteria of either good teacher or effective teacher. Researches on measurement based on good teacher dimensions have been focusing on the teacher itself. The good teacher dimension is observed either from the angle of his or her knowledge, received training, obtained qualifications, behaviour, teaching practice and other aspects directly linked to it. In simpler terms, high quality Arabic language teachers are those who are well-equipped in the field of teaching. The standard teacher package introduced by authorities in several countries is based on the good teacher concept. This includes the Malaysian Teacher Standards (MTS) introduced by the Malaysian Ministry of Education which encompass Arabic language teachers. In line with the adopted concept, MTS provides a specific attention to three standards;

1) Practice of Teaching Professionalism Values Standard

2) Knowledge and Understanding Standard

3) The Skills of Teaching and Learning Standard

Lately, researchers tend to look into the diversity of dimensions contained in the concepts and definition of quality teacher and their link with each other. As proposed by Hanna \& Gimbert (2011) education researchers are advised to construct a model of teacher quality which is comprehensive and holistic. Fenstermacher \& Richardson (2005) for instance considered two dimensions simultaneously namely (1) good teaching and (2) effective teaching. Good teaching involves expectations of teaching profession which must be fulfilled such as possessing certificates, sufficient knowledge in the subject, preparation and the likes. Effective teaching means product of teacher intervention in learning and student learning are also taken into account. Following the same tune, Blanton et al. (2006) viewed that traditional studies which depend on certain understanding of teacher quality should be combined and formulated into several measurement designs. As an example, teacher education 
is linked with teacher quality which in turn is linked with student product. Linking teacher quality with student achievement in particular would attract the attention and acceptance of education policy makers.

Other researchers also voiced the same opinion. They stressed on the importance and necessity of conducting a study which consider all of the indicators and variables which are related to teacher quality (Wayne \& Youngs, 2003; Wichadee, 2010)

The proposition is logical and practical, more so since many variables representing quality teacher which are found to be of high correlation with each other. For example, teacher education level is usually linked with age, experience and academic capability. Certification is frequently correlated with knowledge on the subject, education training and experience (Darling-Hammond \& Youngs, 2002). Goe (2007) is also in favor of combining the dimensions based on her study which outlined the advantages and disadvantages of each determination and measurement mechanism of teacher quality. Viewing teacher quality concepts through diversified dimensions will reduce the weakness and deficiency of assessment which occur when only one dimension is taken into account.

By taking into account propositions by scholars as previously mentioned, this paper therefore proposes that dimensions for Arabic language teacher measurement in Malaysia be inclusive of several dimensions simultaneously.

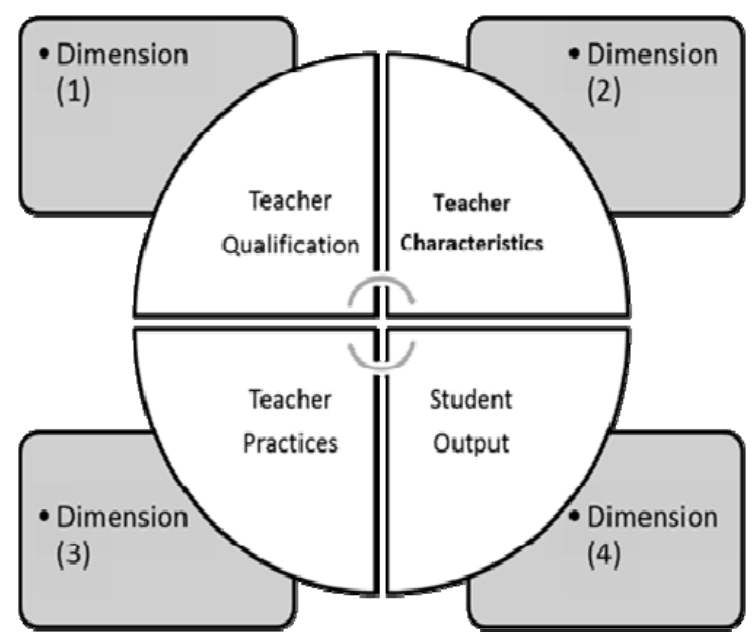

Figure 2. General framework of four (4) measurement dimensions for Arabic language teacher

These four dimensions are only general guidelines on aspects which should be involved in the study and measurement of Arabic language teacher quality in Malaysia. To determine items representing each dimension, a field study must be conducted. Groups linked to Arabic language teacher such as the principal, colleagues, policymakers, teacher training institutions and students are targeted for this study. Their voice is important in determining items for each dimension at the early stage. Their comprehension of each dimension can also be known like, for example, student dimension. Do only examination results represent student output? Or are other aspects like increasing student confidence, interest and expectation in the subject also part of effective student learning output? Besides that, the study is also crucial in weighing the situation of local Arabic language education in line with the concept of quality itself which differs from place to place (Burnett \& Meacham, 2002). Observational study on target groups makes it possible for local elements to be considered in the ala-Malaysia Arabic language teacher quality model.

Burnett \& Meacham (2002) proposed to consider an understanding of teacher quality based on student perspective as compared to what students achieve, what the teacher practices or what qualification the teacher has. This must be emphasized because many studies are based on auxiliary data which are interpreted using supporting sample, not through direct observation or perception of students who are the main target of education. Students are the group which is directly affected by teachers as compared to other group. Moreover, data from teacher observation or self-report were found to be of low credibility compared to those obtained from students (Anonymous, 2010). Nevertheless, Wichadee (2010) proposed that both sets of data be accumulated and compared so that a balance occurs when selection is made. On the teacher's side, it is of great benefit to know which characteristics deemed by the students as those of high quality teachers. 
Further studies are also necessary to ensure validity and reliability of the items of measurement instruments as proposed by Hanna \& Gimbert (2011). Also according to Hanna and Gimbert (2011), the next step is to construct a complete measurement model based on previously determined dimensions and credible instruments. Student achievement is the main output for the process of teaching and learning including that of the Arabic language. In the context of Arabic language education in Malaysia, it was found that the concept of student performance increase was not implemented at all as an indicator for teacher quality. The same scenario occurs in the teaching of other subjects. The Malaysian teacher standard framework and the selection of excellent teachers according to subjects by the Ministry of Education Malaysia through the Inspectorate takes into account the concept of good teacher and not effective teacher. This matter is clearly evident in the criteria previously set in the documents of MTS and Excellent Teacher (see Appendices A and B for complete proofs). Any model or method introduced without effectiveness toward targeted groups is futile. The emergence of analytical technique of Structural Equation Model (SEM) coupled with the invention of various advanced and sophisticated software assists researchers in knowing the suitability of a model or theory in research situation. Besides, Blanton et al., (2006) specified six criteria which can be used to evaluate measurement model for Arabic language teachers namely utility, credibility, comprehensiveness, generality, soundness and practicality.

\section{Conclusion}

Teacher quality is the main factor behind the effectiveness of learning system in schools. Therefore, knowing the dimensions in teacher's quality is fundamental. However, the absence of consensus among scholars in certain dimensions of the quality complicates measurement and evaluation of quality Arabic language teachers. As a solution, a proposal to correlate and combine the dimensions in a measurement framework is presented. To complete, another study is proposed to include several target groups for the purpose of detailing out the proposed dimensions. This study should also be aimed at providing a framework for measurement dimensions of Arabic language teachers with local and specific characteristics so that a module suitable with the Malaysian context can be presented.

\section{Acknowledgements}

This article presents a partial output of a research funded by the Exploratory Research Grant Scheme (ERGS) of the Ministry of Education of Malaysia.

\section{References}

Andrews, S. L. (2012). Impact of Teacher Qualification on Student Achievement at the Elementary and Middle School Levels. (Doctoral dissertation) Walden University.

Anonymous. (2010). A Quality Teacher in Every Classroom. National Board Resource Center. Stanford. Retrieved from http://www.cato.org/publications/commentary/quality-teacher-every-classroom

Blanton, L. P., Sindelar, P. T., \& Correa, V. I. (2006). Models and Measures of Beginning Teacher Quality. The Journal of Special Education, 40(2), 115-127. http://dx.doi.org/10.1177/00224669060400020201

Buddin, R., \& Zamarro, G. (2009). Teacher qualifications and student achievement in urban elementary schools. Journal of Urban Economics, 66(2), 103-115. http://dx.doi.org/10.1016/j.jue.2009.05.001

Burnett, P. C., \& Meacham, D. (2002). Measuring the Quality of Teaching in Elementary School Classrooms. Asia-Pacific Journal of Teacher Education, 30(2), 141-153. http://dx.doi.org/10.1080/13598660220135658

Cavalluzzo, L. (2004). Is National Board Certification an effective signal of teacher quality? Virginia: The CNA Corporation. Retrieved from http://www.nbpts.org/UserFiles/File/Final_Study_11204_D_-_Cavalluzzo_ -_CNA_Corp.pdf

Croninger, R. G., Rice, J. K., Rathbun, A., \& Nishio, M. (2007). Teacher qualifications and early learning: Effects of certification, degree, and experience on first-grade student achievement. Economics of Education Review, 26(3), 312-324. http://dx.doi.org/10.1016/j.econedurev.2005.05.008

Darling-Hammond, L. (2009). Evaluating Teacher Effectiveness. Retrieved from http://www.edgeworksusa.com/ blueprint/files/goe_blueprintforum_pres.pdf

Darling-Hammond, L. (2012). Creating a Comprehensive System for Evaluating and Supporting Effective Teaching. Stanford. Retrieved from http://edpolicy.stanford.edu/sites/default/files/publications/creating -comprehensive-system-evaluating-and-supporting-effective-teaching.pdf

Darling-Hammond, L., \& Youngs, P. (2002). Defining "Highly Qualified Teachers": What Does "Scientifically-Based Research" Actually Tell Us? Educational Researcher, 31(9), 13-25. http://dx.doi.org 


\section{$/ 10.3102 / 0013189 X 031009013$}

Ehrenberg, R. G., Goldhaber, D. D., \& Brewer, D. J. (1995). Do Teachers' Race, Gender, and Ethnicity Matter? Evidence from the National Educational Longitudinal Study of 1988. Industrial and Labor Relations Review, 48(3), 547-561. http://dx.doi.org/10.2307/2524781

Fenstermacher, G. D., \& Richardson, V. (2005). On Making Determinations of Quality in Teaching. Teachers College Record, 107(1), 186-213. http://dx.doi.org/10.1111/j.1467-9620.2005.00462.x

Fuller, E., Young, M., \& Baker, B. D. (2010). Do Principal Preparation Programs Influence Student Achievement Through the Building of Teacher-Team Qualifications by the Principal? An Exploratory Analysis. Educational Administration Quarterly, 47(1), 173-216. http://dx.doi.org/10.1177/0011000010378613

Gallagher, H. A. (2004). Vaughn Elementary's Innovative Teacher Evaluation System: Are Teacher Evaluation Scores Related to Growth in Student Achievement? Peabody Journal of Education, 79(4), 79-107. http://dx.doi.org/10.1207/s15327930pje7904_5

Goe, L. (2007). The link between teacher quality and student outcomes: A research synthesis (pp. 1-72). Washington DC: National Comprehensive Center for Teacher Quality. Retrieved from http://secc.sedl.org /orc/resources/LinkBetweenTQandStudentOutcomes.pdf

Goe, L., \& Stickler, L. M. (2008). Teacher Quality and Student Achievement: Making The Most of Recent Research. TQ Research \& Policy Brief. National Comprehensive Center for Teacher Quality.

Hanna, P., \& Gimbert, B. (2011). Falling Flat: Certification as an Insufficient Indicator of Teacher Quality. Journal of the National Association for Alternative Certification, 6(2). Retrieved from http://www.jnaac. com/index.php/test/article/view/58

Hanushek, E. A., \& Rivkin, S. G. (2010). Generalizations about Using Value-Added Measures of Teacher Quality. American Economic Review, 100(2), 267-271. http://dx.doi.org/10.1257/aer.100.2.267

Ingvarson, L., \& Rowe, K. (2007). Conceptualizing and evaluating teacher quality: Substantive and methodological issues (Vol. 52, pp. 5-35).

Isaacs, M. L., Elliott, E. M., McConney, A., Wachholz, P., Greene, P., \& Greene, M. (2012). Evaluating "Quality" Methods of Filling the "Teacher Gap": Results of a Pilot Study with Early Career Teachers. Journal of the National Association for Alternative Certification, 2(2), 5-22. Retrieved from http://www. jnaac.com/index.php/test/article/view/49

Jasmi, K. A. (2010). Guru Cemerlang Pendidikan Islam Sekolah Menengah di Malaysia: Satu Kajian Kes. (Unpublished doctoral dissertation) Universiti Kebangsaan Malaysia.

Lavy, V. (2011). What makes an effective teacher? Quasi-experimental evidence. Retrieved from $\mathrm{http}: / /$ www.nber.org/papers/w16885

Lee, J. J. (2010). The Uniqueness of EFL Teachers: Perceptions of Japanese Learners. TESOL Journal, 1(1), 23-48. http://dx.doi.org/10.5054/tj.2010.214881

Lin, R., Xie, J., Jeng, Y. C., \& Huang, S. (2010). The Relationship between Teacher Quality and Teaching Effectiveness Perceived by Students from Industrial Vocational High Schools. Asian Journal of Arts and Sciences, 1(2), 167-187. Retrieved from http://203.72.2.115/Ejournal/AM01010202.pdf

Lovat, T., \& Toomey, R. (2009). Values education and quality teaching. Values Education and Quality Teaching. Springer. http://dx.doi.org/10.1007/978-1-4020-9962-5_1

Mat, A. C., \& Soon, G. Y. (2010). Cabaran-cabaran Dalam Pengajaran Bahasa Arab sebagai bahasa asing pilihan di IPT: Kajian kes. AJTLHE: ASEAN Journal of Teaching and Learning in Higher Education, 2(2), 9-21.

Rejab, I. (1992). Masalah Pengajaran dan Pembelajaran Bahasa Arab di Malaysia. In I. A. Rahman (Ed.), Pendidikan Islam Di Malaysia. Bangi: Penerbit UKM.

Smith, E., \& Gorard, S. (2007). Improving teacher quality: Lessons from America's No Child Left Behind. Cambridge Journal of Education, 37(2), 191-206. http://dx.doi.org/10.1080/03057640701372426

Wayne, A. J., \& Youngs, P. (2003). Teacher Characteristics and Student Achievement Gains: A Review. Review of Educational Research, 73(1), 89-122. http://dx.doi.org/10.3102/00346543073001089

Wichadee, S. (2010). Characteristics of Effective English Language Teachers: The Perspectives of Bangkok University Students. BU Academic Review. Retrieved from http://www.bu.ac.th/knowledgecenter/epaper/ jan_june2010/pdf/Page_01.pdf 
Yaakub, M. B. (2007). Teaching Arabic as a second language: An evaluation of key word method effectiveness. Jurnal Teknologi, 46(E), 61-71. Retrieved from http://www.penerbit.utm.my/onlinejournal/46/E/JT46E JUN4.pdf

\section{Appendix A}

\section{Malaysian Teacher Standard (MTS)}

The Teacher Training Division (TTD) of the Ministry of Education Malaysia had taken the initiative to formulate a teacher standard as a guideline and reference for teachers, teacher trainers, agencies and teacher training institutions in Malaysia. The standard covers the following three aspects:

\section{Standard 1: Practice of Teaching Professionalism Values}

This standard details the competencies in the practice of teaching professionalism values based on personal domains, professional and social which should exist in a teacher. The Practice of Teaching Professionalism Values is drafted based on the culture at Institutes of Teacher Education (ITE), Code of Conduct of the Teaching Profession, the values in the school curriculum, core values in the Civil Service, the main principles of the MOE Work Ethics, and The Twelve Pillars.

\section{Standard 2: Knowledge and Understanding}

This standard details the competencies in knowledge and understanding on specialization subjects, the science of education, curriculum and co-curriculum which should exist in a teacher. A teacher who possesses and masters a solid grasp of the knowledge boosts teaching professionalism, discharging duties efficiently and effectively as well as becoming more creative and innovative.

Standard 3: Teaching and Learning Skills

This standard details the competencies of teaching and learning skills which a teacher should command. This standard focuses on teacher ability to plan, implement and evaluate academic and co-curricular teaching and learning.

\section{Appendix B}

\section{Ministry of Education Malaysia Excellent Teacher Characteristics}

Excellent Teacher has the following characteristics in terms of quality:

Personality: An Excellent Teacher is one who has a praiseworthy character, is competent and adherent to teaching and civil service work ethics as well as sensitive and concerned with student needs who can become a role model for teaching fraternity.

Knowledge and skills: An Excellent Teacher is one who masters and appreciates the subject content or specialization field and its expertise, a reference for teaching and learning, wise in managing time, resources, teaching and learning tools, capable of identifying needs and learning problems of the students and preparing follow-up actions, as well as knowledgeable and skillful in information and communication technology.

Handiwork: An Excellent Teacher is one who is capable of increasing learning outcomes towards developing student potential in line with the National Education Philosophy.

Communication: An Excellent Teacher is one who possesses a high communication skill and is capable of delivering ideas and messages effectively in various situations.

Potential: An Excellent Teacher is one who is visionary, proactive, has initiatives, characteristically responsive and innovative within the framework of discharging duties as an educator.

Contribution to progress in national education: An Excellent Teacher is one who is able to generate new ideas in his or her own subject or specialization and share the ideas to increase the quality of national education.

\section{Copyrights}

Copyright for this article is retained by the author(s), with first publication rights granted to the journal.

This is an open-access article distributed under the terms and conditions of the Creative Commons Attribution license (http://creativecommons.org/licenses/by/3.0/). 